\title{
Būtiškosios šviesos spindèjimas Ričardo Mikutavičiaus lyrikoje
}

\author{
INGA STEPUKONIENE \\ Vytauto Didžiojo universitetas, Lietuvių literatūros katedra, K. Donelaičio g. 52-212, LT-44248 Kaunas \\ El. paštas: i.stepukoniene@hmf.vdu.lt
}

\begin{abstract}
Straipsnyje aptariamas Ričardo Mikutavičiaus, vienos charizmatiškiausių XX a. antrosios pusės lietuvių tautos asmenybių, religinès lyrikos krypties savitumas, krikščioniškosios meditacijos, ženklinančios dieviškojo pasaulio paslaptingumo, tikejjimo ir atsidavimo Dievo valiai, didžiosios Tiesos ir Prasmés paieškas. Jo poetineje perspektyvoje akivaizdžiai susikerta dvi strateginès linijos: dvasininko, Kristaus tiesos ir meilès skleidejo, ir kultūrininko, pasišventusio tautai, jos dvasios gaivintojo, pozicijos. Iš čia kyla poeto kūryboje dvasinès tarnystès ir iš Evangelijų ateinanti meilès atnašavimo laikysena, tautos kultūrinių pagrindų ir dvasios namų ieškojimas. Būdingas poeto kūrybos bruožas - pakilus eilèraščiu tonas, religijos siejimas su kultūra. Darbo metodai: analitinis interpretacinis, aprašomasis, fenomenologinis.
\end{abstract}

Raktažodžiai: R. Mikutavičiaus poezija, religinė poezijos kryptis, krikščioniškoji meditacija

\section{IVADAS}

Ričardas Mikutavičius - neabejotinai viena iškiliausių ir charizmatiškiausių XX a. antrosios pusès lietuvių tautos asmenybių: kunigas karštai rūpinosi žmonių sielovada, buvo nepakartojamas pamokslininkas, kurio klausytis nuolat suplaukdavusi žmonių jūra, uolus kultūrinio tautos paveldo saugotojas - bažnyčių restauratorius ir meno kūrinių kolekcininkas. Jis nuolat aktyviai dalyvavo visuomeniniuose procesuose, juos skatino ir kreipe savita vaga, besąlygiškai rūpinosi tautos dvasiniu atgimimu.

Ričardas Mikutavičius gimè Kaune. Čia prabėgo jo vaikystès ir jaunystès metai, čia 1958 m. baige kunigų seminariją. Šiame mieste, Šv. Antano bažnyčioje, laikytos pirmosios šv. Mišios ir pradètas dvasininko kelias. Vèliau klebonavo Eržvilko, Kelmès, Panevėžiuko, Žeimelio, Lauksodžio, Seredžiaus, Tytuvėnų parapijose. Kunigas visuomet rūpinosi bažnyčių architektūra. Gyvendamas Tytuvėnuose restauravo bažnyčią ir vienuolyno pastatus. Su visais maloniai bendravo, buvo šiltas, nuoširdus, įsiklausantis ị kiekvieno rūpesčius, negailintis patarimo. Dar giliu sovietmečiu pasižymėjęs kaip puikus oratorius buvo kviečiamas $\mathfrak{i}$ kitas parapijas, važiuodavo sakyti pamokslų i Vilnių [4, 64].

Jo žodis itin gyvai suskambo atgimimo laikotarpiu, kai kunigas buvo paskirtas dirbti Kauno Vytauto bažnyčioje. Apsigyvenęs Juozo Tumo-Vaižganto bute, jis tarsi perėmé šios legendinès asmenybès dvasią. Mažutè barokinè bažnytėlè tapo tikraisiais jo namais: iš čia skambejo jo maldos ir giesmès, poetinis žodis, kuris šaukte šaukè kiekvieną stagnacijos 
gniaužtų nualintą, pavargusią, suskurdusią sielą. XX a. antrosios pusės lietuvių visuomenè, nors ir tebelaikè save tikinčia, bet daugeliu atvejų taip ir neatsivèrè tikrajai dievoieškai. Subtilus kunigo Ričardo Mikutavičiaus žodis neabejotinai daugeliui priartino, atskleidè Kristaus tiesą, susiejo su ja paprastai, bet giliai, pabudindamas sąmonę, pažadindamas protą. Atgimimo laikotarpio Kaunas tiesiog neịsivaizduojamas be Ričardo Mikutavičiaus - plačiais sutanos skvernais energingai plasnojančio Laisvès alèja, kiekvienam sutiktajam spinduliuojančio savo aura, dalijančio šypsenas ir ikvejpimo, paguodos, palaikymo žodžius. 1997 m. iš Vytauto bažnyčios perkeltas dirbti ị Šv. Dvasios (Igulos) bažnyčią jis tapo gyva Laisvès dvasia, jos simboliu, kaip ir tinka kunigo misijai - tiesos ir šviesos skleidejju, kiekvieno draugu. Kaip ir anksčiau, rūpinosi sovietmečio suniokotos bažnyčios rekonstrukcija - ketino ne tik atnaujinti šventovès išorę, fasadą, bet, kaip prisimena V. Žukas, „suteikti kitą dvasinị ir estetinị veidą“ jos vidui, „bažnyčią paversti lyg panteonu, papuošti įžymių Lietuvos žmonių biustais, paminklinėmis lentomis (vyskupo Mečislovo Reinio, profesoriaus Prano Dovydaičio skulptūros, kunigo Juozo Zdebskio metalinè memorialinè lenta su bareljefiniu portretu)“, Lietuvos globèjo šv. Kazimiero skulptūra [4, 65].

Kunigas aktyviai dalyvaudavo visuomeninèje ir akademinèje veikloje: sakẻ kalbas įvairių miesto renginių ir švenčių metu, skaitė paskaitas atkurtame Vytauto Didžiojo universitete, rengdavo pranešimus konferencijoms. Kauniečiai dar šiandien puikiai prisimena jo surengtą 580-ųjų Žalgirio mūšio metinių paminèjimą Kauno Vytauto bažnyčioje: minios suplūdusių žmonių, užtvindytos gretimos gatvès, radiofikuotas šventorius. Ir be galo emocingas, patriotiškas bažnyčiaus rektoriaus R. Mikutavičiaus pamokslas „su digresijomis ị senąją Lietuvos praeitį, Vytauto asmenybės reikšmę Lietuvos istorijai ir dabartinę politinę situaciją" $[4,64]$. Poetas dalyvavo atidengiant Laisvès alëjoje paminklą Vytautui Didžiajam, jị pašventino. Kai iš Kauno Nepriklausomybès aikštės Petrašiūnų kapinėse buvo nuspręsta perlaidoti poetę Salomèją Nèrį, jis pasakè kalbą, kurioje prisiminè nuostabią poetès kūrybą, apibendrino žmogaus gyvenimo kelio tragizmą, jo sẻkmes ir nesẻkmes, dvasinių kataklizmų kupiną būtį. Jis dalyvavo susitikimuose su studentais ir moksleiviais, meno parodų atidarymuose, literatūriniuose vakaruose. Dažnai skaitė savo kūrybą: eilèraščius, eilèraščių ciklus, dalyvavo diskusijose apie literatūrą, meną, religiją, tikejjimą. Visuomet buvo geranoriškai atviras visuomenei, pasirengęs išklausyti, dalytis mintimis, ieškoti naujų horizontų sau ir kitiems.

Maironio lietuvių literatūros muziejaus direktorė Aldona Ruseckaitė prisimena kunigą kaip uolų literatūrinių sambūrių Kaune organizatorių. Tokius pasibuvimus savo namuose rengdavo šeštadieniais, trečiadieniais arba ketvirtadieniais. „Vakarai buvo prestižiniai - rinkdavosi inteligentijos elitas. <...> Visuomet su programa - skaitomos eilès, kalbama apie naujas knygas, klausomasi muzikos. Koncertai vykdavo viename kambaryje, o kitame buvo didelis stalas, paprasti, bet geri indai - peiliai, šakutès, lèkštelès, cukrinès. Buvo ir sidabrinių indų“ [4, 66]. Dalyvaudavo daug akademinès aplinkos žmonių, profesorių, dėstytojų; „iš meno pasaulio - rašytojai Petras Palilionis, Robertas Keturakis, aktorius Aleksandras Rubinovas, buvęs Kauno muzikinio teatro solistas, režisierius Stanislovas Rubinovas, žurnalo „Santara“ redaktorius Romualdas Norkus, kompozitorius Giedrius Kuprevičius“ [4, 66]. Kai mieste steigiant J. Tumo-Vaižganto muziejų darbuotojai stengèsi atkurti rašytojo biblioteką, kurios didelè dalis kadaise atiteko Technologijos universitetui, R. Mikutavičius iš savo kolekcijos padovanojo 387 iškiliojo lietuvių rašytojo leidinius bei jam įteiktą Lietuvos didžiojo kunigaikščio Gedimino ordino žvaigždę, kurią nupirko iš kolekcininko už tūkstantį dolerių $[4,66]$.

Išskirtinis R. Mikutavičiaus pomėgis - kolekcionavimas. Anot Marcelijaus Martinaičio, tai toli gražu nebuvo azartinis interesas ar komercinis tikslas - poetui buvo svarbus , asmeniš- 
kas santykis su meno kūriniais, estetiniai motyvai“ [4, 65]. Jị visuomet labai jaudino ir skaudžiai žeidè faktas, kad Lietuva buvo praradusi didžiulį aristokratiškajị kultūros paveldą: karų ir istorinių sumaiščių laikotarpiu ištuštinti dvarai, vienuolynai ir bažnyčios, išgrobstytos unikalios meninès ir kultūrinès vertybès. Todèl dar sovietmečiu kunigas R. Mikutavičius kaupè viską: ìvairių pasaulio dailininkų tapybos darbus, taikomosios dailès kūrinius, skulptūras, žvakides, staliukus, sietynus, kẻdes, lèkštes ir t. t. Pirko iš kolekcininkų, meno ir senovinių daiktų prekeivių, gaudavo dovanų iš bičiulių ar meno mėgejjų. Kolekciją buvo nusprendęs padovanoti Lietuvai. Taip ir padarè: didžiulè Vakarų Europos paveikslų dalis atiteko Kauno M. K. Čiurlionio dailès galerijai. Kita tikriausiai tapo jo mirties priežastimi. 1998 m. liepos 1 dieną ị savo namus ịsileidęs pažįstamus žmones Ričardas Mikutavičius dingo be žinios. Vèliau rastas kūnas palaidotas kaip neatpažintas. Ir tik atlikus ekshumaciją ir nustačius asmens tapatybę, garbingai palaidotas Petrašiūnų kapinèse - žymus kūrẻjas amžino poilsio atgulè šalia lietuvių poetės Salomėjos Nėries. Laidotuvės priminė Juozo Tumo-Vaižganto ir Stepono Dariaus bei Stasio Girèno: lydinčiųjų vilkstinè iš Žemès ūkio akademijos iki amžinojo poilsio vietos buvo nusitęsusi penkis kilometrus, dešimtys tūkstančių žmonių lydèjo gatvėmis, stebėjo iš balkonų, pro langus $[4,67]$.

Ričardas Mikutavičius Kauno gyvenime - ir vienas savičiausių laikotarpio poetų, tęsęs ir plètojęs lietuvių poetinejje kūryboje krikščioniškosios tematikos ir pasaulejjautos liniją. Šia prasme mūsų kultūroje jis akivaizdžiai stoja ị kunigų kūrẻjų - Maironio, A. Baranausko, A. Vienažindžio, J. Tumo-Vaižganto - gretas. Šio modernaus kūrèjo poezijoje gyvai atgimsta giliai tikinčio žmogaus pasaulèvoka, ne prieštarų ir abejonių, egzistencinio dvilypumo kankinamo subjekto išgyvenimai, bet aiškiai savo kryptị žinančio žmogaus būties apmąstymai. Tikejjimas jo poezijoje suvokiamas kaip tiesa, egzistencinès šviesos šaltinis, atraminis taškas visai žmogaus būčiai, be kurio neįmanomas prasmingas buvimas. Tai religinès lietuvių poezijos kryptis. Literatūros tyrẻjas R. Skunčikas išskyrè tris sakrališkumo lietuvių poezijoje formas: 1) empirinę (istoriškąją) religijos elementų, ịvaizdžių, veikejjų interpretaciją, peraugančią ị sentimentalų iliustratyvumą, iš esmès svetimą lyrikos prigimčiai; 2) neoromantiškąją Dievo refleksiją, besiremiančią lyrinio subjekto nerimasties ir ilgesio, kančios ir aukos išgyvenimais, atskleidžiant Dievo ieškančio žmogaus regimąją ir transcendentinę būtị (J. Kossu-Aleksandravičiaus, B. Brazdžionio lyrika); 3) krikščioniškają meditaciją, ženklinančią dieviškojo pasaulio paslaptingumo, tikejjimo ir atsidavimo Dievo valiai, didžiosios Tiesos ir Prasmès paieškas (L. Andriekaus, R. Mikutavičiaus, K. Trimako kūryba) [2, 27]. Medituoti dieviškąą tiesą ir paslaptị, religijos ir tikejjimo inspiruotą dvasini ịkvèpimą - vienas svarbiausių poeto meninio pasaulio tikslų. Kaip teigia Marcelijus Martinaitis, būdingas R. Mikutavičiaus kūrybos bruožas - pakilus eilèraščių tonas, religijos siejimas su kultūra; tai autentiška poezija, atitinkanti „autoriaus charakterị, elgseną, santykius su žmonėmis“ $[4,65]$. Tad šiame straipsnyje ir sieksime pažvelgti, kokia krikščioniškoji refleksija atsiveria poeto lyrikoje, kaip joje medituojamos žmogiškosios būties prasmès, kaip siekiama būtiškosios šviesos.

\section{GOTIKOS SPALVOS}

Ričardas Mikutavičius išleido keletą poezijos rinkinių: $1988 \mathrm{~m}$. lietuvių skaitytojus pasiekè eilèraščių knyga Kad Lietuva neišsivaikščiotų, 1990 m. - Poterių upe, 1992 m. - Šviesos spalvos, 1995 m. - Žaizdos metafizika, 2004 m. pasirodè jau gerokai anksčiau, dar gyvenant Babtuose, parengta, bet dienos šviesos ilgai neišvydusi eilèraščių knyga Kryžiaus kelio mąstymas, skirta Lietuvos krikšto jubiliejui. R. Mikutavičiaus poeziją vienija ị religinị pagrindą 
atsiremiantis filosofinis būties klodas, gyvas egzistencinès paslapties jutimas, uolus skverbimasis link dvasinių tiesų atverties, gyvybės ir būties stebuklo išgyvenimas. Jo poetinėje perspektyvoje akivaizdžiai susikerta dvi strateginès linijos: dvasininko, Kristaus tiesos ir meilès skleidejjo, ir kultūrininko, pasišventusio tautai, jos dvasios gaivintojo, pozicijos. Iš čia kyla poeto kūryboje pagrindinè dvasinès tarnystès ir iš Evangelijų ateinanti meilès atnašavimo laikysena, tautos kultūrinių pagrindų ir dvasios namų ieškojimas. R. Mikutavičius savo poezijoje plačiai atsigręžia į tautą - i paprastą jos žmogų, varginamą sunkios gyvenimo naštos ir patirties, ị tautos kultūros raidą skatinusių asmenybių likimus, ị tautinę bendruomenę kuriančius kultūrinius matmenis, gilumines sroves, vaizdžiai savo poezijoje brèždamas naujos būties prasmès orientyrą - visokeriopą tautos dvasios aktualizavimą ir jos išlaikymą.

R. Mikutavičiaus eilèraščių poetikos pagrindas - ramus kalbejjimas, vietomis perpintas antinomijų, opozicijų, dramatiškų sandūrų, atspindintis didelị sąmonės aktyvumą. Dažnai atsisakoma tiesaus minties formulavimo, jos išbaigtumo. Išlaikoma pastovi laikysena, susieta su Dievo pažinimu ir žavejjimusi jo sukurtu pasauliu, igalioto kalbejjimo strategijomis. Eilèraščiuose ryški religijos ir kultūros jungtis, atsiverianti ypatinga simbolika, kultūros kontekstais, kultūroje pabrèžiamais sacrum elementais. Poetui religija ir kultūra - esmingiausi sandai, sudarantys pasaulio būties esmę, nedalomai susiję. Žmonijos istorijos raidoje jie eina kartu; todèl poetas įdèmiai žvelgia Lietuvos praeitin, bandydamas prisiliesti, pajusti, išsaugoti, naujai pamatyti šiuos fenomenus, palikusius ženklus kiekvienoje epochoje. Taip naujai iškeliami gilieji vertybiniai pamatai ir suteikiama impulsų kitokiai būties perspektyvai.

Vienas meniškiausių poeto kūrybos rinkinių - Šviesos spalvos [1]. Kaip pažymèjo literatūros tyrejjas T. Nemčinskas, joje itin svarbi yra architektūrinè poetika [3, 8]. Pirmojoje knygos dalyje "Gotikos sakramentas“ daug demesio skiriama gotikai - epochai, palikusiai nepaprastus „irašus pasaulio istorijos knygoje“ [3, 8]. Lietuvoje tai - Vilniaus katedra, raudonųjų plytų smailiabokštė Vytauto bažnyčia, t. y. objektai, tapę didžiosiomis kultūros vertybėmis. Savitų architektūrinių formų bažnyčios - išskirtinis gotikos epochos palikimas pasauliui; estetiškose bokštelių smailèse, baltose sienose tiesiog i̇sikūnijęs dvasingumas, ramybès ir harmonijos pulsavimas: Gotikos viduryje / raudonoje žolejje / permatomais rūbais / Dangus / ir Angelai... („Gotikos viduryje...“, p. 46). Poetas tapo gotišką bažnyčios erdvę: grakščius skliautų lankus, kupolus, sienų linijas, navas, vitražų spalvas, atkurdamas visų formų plastiką, reflektuoja ịstabų architektūros groži („liekna kolona - / akmens gèles kapitelis - / ne, tokio išdidumo / išmokti negalima“...; „liekna kolona“, p. 58), kurị dar labiau paryškina „šventujų choralo kuždesys“. Gotikinè bažnyčia jam - pasaulio tobulumą transcenduojanti vieta, tikrojo grožio ir gèrio susikirtimo taškas, harmonijos, nuskaidrèjimo, visapusiško sielos nušvitimo erdvè, spinduliuojanti „Gotikinès Madonos ramybę“ („puokštè paveikslų“, p. 56). Nepakartojamų architektūros, dailès, muzikos pasaulių susiliejimas sukuria sielos pažadinimo aktą: „Gotikos Gerumas / nepraeis nepalietęs („grakštus“, p. 60); Kolonomis aukštyn / srovena / Te Deum Laudamus, / Te aeternum, / tyros smiltys - / sienomis žemyn / lyja / Unus Sanctus, / Unus Benedictus / baltas tyrumas“" (p. 61). Gotika poeto eilèraščiuose tampa šventumo analogija, sublimuojasi i sakramentą, virsta maldos turiniu: „teesie / Gotikos / šventas vardas! // Gotikos karalystè teateinie / ant kasdienybiu!“" („teesie...., p. 7). Poetui svarbi šventumos nuojauta, jos ieškojimai, jos refleksija, greta to - mąstymo būsena, minties prioritetas, lemiantis šios poezijos filosofinị kontekstą: „mainau / Saule i Vilti - / pati léčiausia, / be apsiausto ir vainiko / marga minties Upé / nenukankinta kad tekètu...." („mainau..., p. 8). 
Kūrybinę savivokos trajektoriją rinkinyje brèžia iš krikščioniškosios religijos sklindantis šviesos laukas, programuojantis naujų egzistencinių pasaulių kosmogoniją:

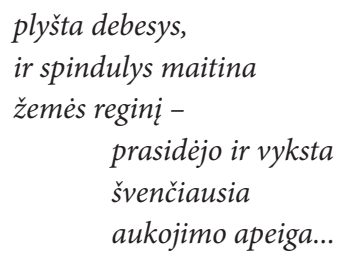

Šviesa - svarbiausias poeto minties ir jausmo polius. Kosmogoninis vyksmas - atbudimas - regimas visoje Visatos erdveje. Aktualizuojamos visos šviesos simbolinès prasmès - saulè, spindulys, žvaigždès. Taip atsiveria unikalus, savitas pasaulio, Dievo ir žmonių suvokimas: lyrinio „aš“ egzistencijos kryptis aiškiai projektuojama gèrio ir grožio, būties taurumo, tolerancijos ir visapusiško supratimo, pagarbos ir žavejjimosi Dievo sukurtu pasauliu, visomis jo formomis linkme. R. Mikutavičius laisvosiomis eilèmis poetiškai pakiliai itprasmina religinį jausmą, evangelinę mintị. Jo eilutės - trumpos, mėgstama talpi, lakoniška forma. Rinkinyje itin dažna reiškinių ir prasmių kilmès, kosmogoninè, situacija, tiesiogiai susijusi su šviesos prasminiu lauku:

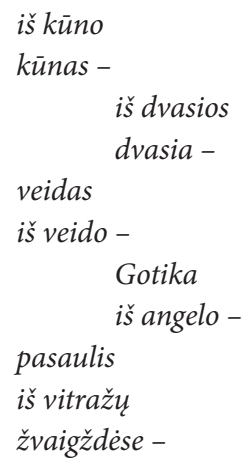

(,,iš kūno....", p. 10)

Kitas pasaulio kosmogonijos, egzistencijos tapsmo ir prasmingumo įteisinimas - žemès susiejimas su Aukščiausiojo valia, paklusimas jai: „žemé suauginta / su Kūrëjo ranka / ir prisaikdinta / švenčiausiu / Gotikos sakramentu“ („žemė suauginta...“, p. 11). Šis ypatingas žemès ir dangaus ryšys - visos žemès gyvybès susiejimas su šviesos poliumi, kryptingas jos orientavimas i gèrio ir grožio, taurumo ir kilnumo viešpatiją. Tai žemei Dievo dovanotas meilès kelias, kuriuo einantis naujai atranda save, savo šviesą gali skleisti kitiems. Tai dvasinio tikrumo, naujos būties pažadinimo kelias, kuriuo einantis išgyvena tikrąji būties išsipildymą, patiria dvasios katarsị, atranda tikruosius gyvybinius šaltinius, tikrąsias prigimtines žmogaus galias - mylèti ir kurti. Poeto kūryboje metaforiškai itteisinama mintis, kad Dievas ir žmogus susitinka gotikinejje bažnyčioje, kuri tampa žmogaus dvasios kosmogoniją icentrinančia vieta, sakralia erdve (yra Du - / Dievas ir Žmogus - / bet dar ir juos gaubianti / ir jungianti gotikos Dvasia / (ir dar yra tuščia žemè) („Yra Du...”, p. 14). Dievas kviečia žmogų kilti iš nykaus tamsos ir tuštumos poliaus; šviesos ir tamsos priešpriešos îprasminamos mitologinei ir religinei sąmonei būdingomis dichotomijomis juoda - balta, 
gera - bloga. Tuštumą reprezentuoja leisgyvio pasaulio, blunkančios žemès spalvos, vergovès metų metaforika ir ịvaizdžiai. Lyriniam „aš“ yra svetimas bet koks nebūties ženklas, žmogus suvokiamas kaip jungties su anapusybe mediumas, jos šviesos (iš)spinduliavimas žemèje - eilèraščiai atspindi ši jo sąmonès tapsmą:

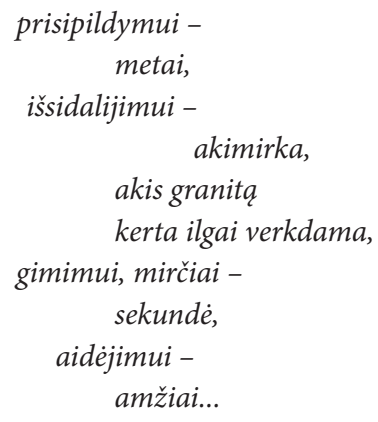

(„prisipildymui...“, p. 17)

Eilèraščių nuotaika ypatinga - iškilminga, pakili. Tarsi jaučiama būties, visatos, šviesos jèga - galingi lemtingų akimirkų dūžiai. Tas tapsmas, giluminis pasaulio būties pažinimas, moralinè ir dvasinè transformacija yra nuolatinè: „kai klausau, / kančia / gieda / mirtimi / ir prisikèlimu - / pasineriu / ị pradžiu / gelmę - („kai klausau...“, p. 18). Dvasia ir siela - dažnos sąvokos, ịprasminančios susikaupimą, rimtį, gelmę, tikslingą prasmingumą: „sleppinyje dvasia, / už kūno, / prie kruvinai / atsišaukiančios širdies..." („slëpinyje...", p. 20). Jis tvyro poetiniame lyrinio „aš“ saviportrete - kūno ir dvasios susiliejime, siekiamos idealybès projekcijoje:

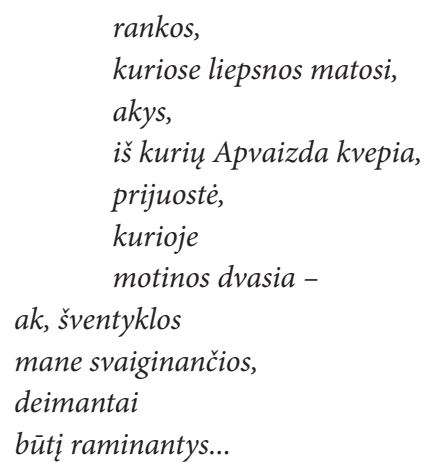

Poetizuojama galia, kibirkščiuojanti energija, slypinti kažkur giliai viduje, ịslaptinanti egzistenciją. Vienos svarbiausių rinkinyje - žmogaus, kunigo pašaukimo žemèje bei dvasinio ¡kvejpimo temos. Nuolat pasikartojantis ritualinis aukojimo ir savęs atnašavimo pasauliui aktas įteisina jo atgimimą, kūrimą iš naujo: „mazgosiu vandeni - / atšildysiu ugnị - / atšventinsiu apeiga - / bet ka daryti su duona, / kuri yra prisilietimas / ikaitintu gundymu?" („mazgosiu...", p. 25). R. Mikutavičiaus poezijoje itin dažna švytejjimo, spinduliavimo, skaidrumo metaforika, ịprasminanti dvasinio atgimimo, atbudimo prasmę („, iš taško / i labai labai / ilga linija - / iš visišku / pelenų susideginus / ị pilna švytëjima!!“; „iš taško...", p. 31). „Saulę / i Šviesa išnešu - / Būtį / iš paties pragaro tvaiko..." (p. 34) - sąmoningai įteisinama lyrinio „aš“ 
kaip dieviškosios tiesos apreiškejjo, pranašo pozicija, jo dvasinis kryptingumas ị harmonijos, taurumo ir šviesos polių, būtinybe egzistenciškai įveikti tamsos jẻgas ir skelbti gerąją žinią pasauliui („taip nelengva / eiti aukštyn / vaivorykšte“; „po visų Sekminių“, p. 22). Tai vidinė subjekto motyvacija, rinkinyje sudaranti darnią ir vientisą trajektoriją. Dievą ir žmogų sieja giluminė tarpusavio sąveika ir ryšys, Dievas skatina žmogų prasmingam dvasiniam judesiui ir veiksmui. Jo vidus tarsi prisodrintas kosmogoninio vyksmo, jis skleidžia ypatingą nuotaiką, kuria naują - harmonijos ir meilès tikrovę. Poeto kūryboje matyti absoliutus atsitolinimas nuo vienpusio pragmatizmo ir materialumo, ikvejpimo ieškant po dvasingos gotikos architektūros - bažnyčios bokštais ir skliautais, gamtos artumoje („ištuštèji ir prisipildai / blizgesyje <...> brendi, bègi dugnu / pas neužliejama saule - - / myli mane gotikos gelme - joje mirštu ir gimstu, / iš naujo prausiu / išniekinta / sutvirtinimo sakramenta“; ,išveda...., p. 26). Pagrindinè rinkinyje - kilimo aukštyn vertikalè; ją atspindi ir ịspūdinga analogija: vinimi perkaltas Kryžius ir spinduliu pervertas Paukštis: - „panūdę kilti - / abu prie dangaus pririšti..." (p. 28). Kryžius poeto kūryboje ịprasminamas kaip ypatingo kančios kelio - fizinès mirties ir dvasinio atgimimo simbolis: „kojomis ir rankomis / išpažistama Mirtis - / dvasia ir akimis / pakeliamas Prisikèlimas“ („kojomis ir rankomis...”, p. 29). Subtiliai, nejučia pereinama į maldos diskursą: „DIEVE, virstančioj griuvésiais žemès šventovej / duok Savęs / man mažą, / neišnykstančia kruopelytę - / ties Büties siena / tvenkiasi nenuplaunamas / išsekimo ir praradimu kvapas...“ („DIEVE...“, p. 38). Nuolat siekiama apibrèžti savo vietą visatos kosmose: „Grįžtantis Paukštis / danguje - / o kur aš, / žeme?“ („Grįžtantis Paukštis“, p. 51).

\section{ŽMOGUS-KUNIGAS-POETAS}

Taigi svarbiausias rinkinyje - žmogaus-kunigo-poeto egzistencijos orientyras, kryptingai ịprasminantis misijos suvokimą. Pirmiausia ypatingas dėmesys skiriamas žodžiui („Žodis? / supančiotas ir laisvas Gotikos paukštis“; „Žodis“, p. 42); kunigas turi žodi - galimybę skleisti Evangelijos tiesas, žodị, kuriuo krikščionybe per ištisus šimtmečius pasaulyje pasiekè tiek daug. Žodis - svarbiausias ir poetui; jo suvokimu, tai yra „viskas viskas“, jis „lyg Upé, / Žuvis, / Medis / ar net Skara“ (p. 36). Taip, tarpusavyje susiejant skirtingus archetipus (vanduo - visatos kosmogonijos elementas, žuvis - krikščionių religijos simbolis, medis - pasaulio sandaros simbolis, skara - motinos meilès metafora), sukuriamas ịstabus ir platus žodžio galios laukas. Žodis - paliečiantis sielą, nuprausiantis, apvalantis, plukdantis tolyn, î̌šknijantis, apgaubiantis, sušildantis. Poetas-kunigas, tarsi sąmoningai nutoldamas nuo religinių dogmų, atveria gilųj j savos būties prasmès orientyrą.

Vienas matomiausių R. Mikutavičiaus kūrybos momentų - savo, kaip kunigo, identiteto refleksija, dvasininko vidinių ieškojimų ir atradimų kelias: noras pažinti, kaskart naujai atrasti Kristų, aprépti Jo šviesos begalybę, pajusti savyje dieviškąją malonę. Eilèraščiuose atsiveria lyrinio subjekto dvasinès būsenos - sielos alkis, troškimas, katarsio, asmeninio išsipildymo ir apsivalymo laukimas, dvasinès ekstazès potyris („noriu / nuvesti save / gilyn, / išsiverkti / noriu / iki pažinimo, / noriu ragauti / ǐšipildymo / kartumo“; „noriu....", p. 41). Dažnai reflektuojamas kunigo, atliekančio svarbiausią savo egzistencinę misiją - pasaulio apvalymo aktą, dvasinis būvis, liudijantis asmenybės sielos susiliejimą su dieviškuoju šviesos lauku: „krentu / i begalinès šviesos / Taurę - / atsistoju / pačiame Kryžiuje / šventovès vidurinëje navoje - / gyvenu / ir gimstu, / kalbu ir giedu..." („krentu...", p. 45). Kunigas - dvasios ir šviesos sklaidą ịcentrinanti žmogiškoji būtis. Kaip ir K. Trimako poezijoje, tai Visatoje meilę transcenduojantis ir krašto dvasia dieviškumui nusilenkiantis mediumas: 


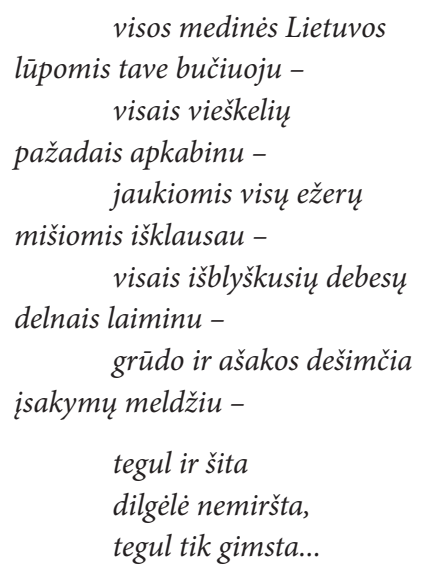

(,visos...", p. 82)

Pagrindinę probleminę aši poeto eilèraščiuose konstruoja žmogaus-kunigo, kuriam lemta išgyventi savą dramatišką žmogiškąji likimą („žmogus esu / ant nukryžiuotos / že-

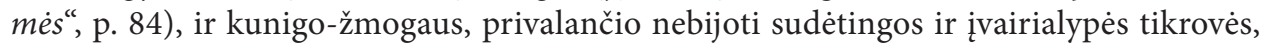
gebančio perprasti ir giliai svarstyti gyvenimo reiškinius, pozicijos („erdvę jaučiu, / neišsigastu / jos visiško nuogumo, / žinodamas, / kad tas vitražas - / ne naktis / ir ne diena“; „erdvę jaučiu....", p. 63). Filosofinis būties apmąstymas poetiniuose kūriniuose grindžiamas moralinėmis ir religinėmis - pasiaukojimo, prasmingos kančios - kategorijomis, kurias privalu gerai įsisąmoninti. Ir žmogaus, ir kunigo gyvenimas ịprasminamas kaip amžina kelionè link tikrojo sielos apsivalymo, nuskaidrèjimo ir savęs atnašavimo pasauliui. Todèl reikšmingas tampa kelio, kelionès archetipas, atveriantis būties sudètingumą: „slenku / i Emausą - / negaliu / paniekinti pranašu / ir keisto Nazaretiečio. / tvankiame kelyje / mirštu / ir atgyju / nuo ieškojimo / ir praregéjimo“ („Emausa““, p. 73). Skaudūs Kristaus tarnystei pasišventusiojo potyriai leidžia savo išgyvenimus gretinti su Jo, ieškoti didžiosios patirties aido savo būtyje:

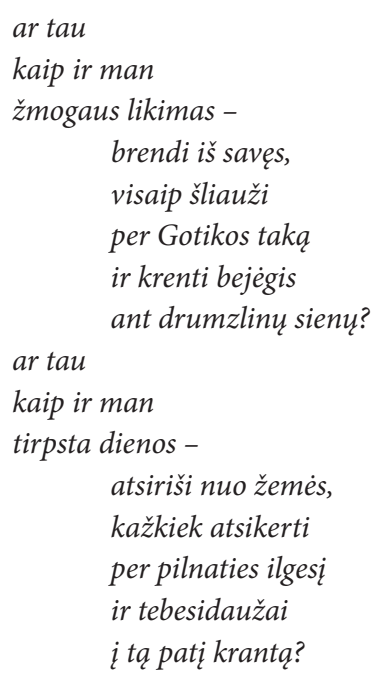




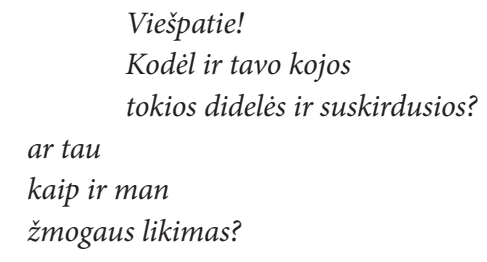

\section{(„Likimas“, p. 108)}

Dievoieškos ir Dievo pažinimo kelyje svarbus tampa jutiminis pradas, gebejjimas išgyventi, pajusti tikrąją būties šviesą - Aukščiausiąją esatị. İspūdinga ir visas poezijos prasmes sutelkianti samprata - Evangelijos atsivėrimas žmogui - atsiskleidžia sielai, prakalba i̇ ją šviesos pavidalu:

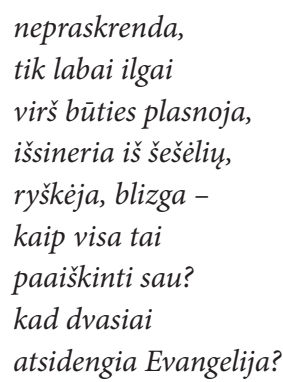

(„nepraskrenda“, p. 74)

Taip atrandamos svarbiausios kategorijos, be kurių neįmanomas harmoningas žmogaus buvimas pasaulyje. Tai šviesa, tiesa, harmonija, laimė; jei jų nèra, „iš kur atsiras Dievas / ir ilgai šalia pabus?“" („šviesa...", p. 75). Pasaulio sanklodos centrinės ašys - dvasia ir Viešpats, didžioji Šviesa, didysis Visatos paslaptingumas:

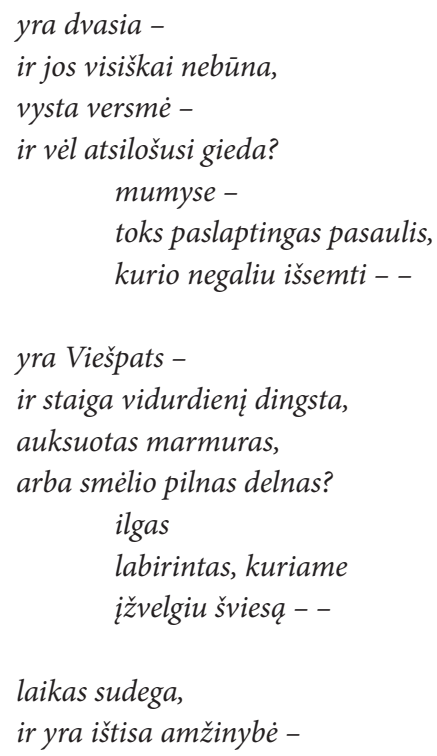




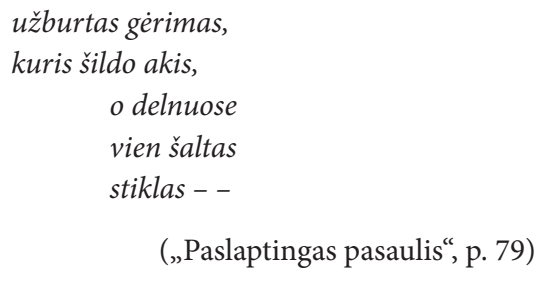

Dievas atnešęs pasauliui amžinybės erdvę, nuolatinę galimybę atsinaujinti ir kurti, alsuoti gėrio šviesa, nutolinančia nuo šiurkščios realybės. R. Mikutavičiaus poezijoje gyvenimas suvokiamas kaip buvimas Dievo dovanotose „šviesos spalvose“ - nesiliaujančiame šviesos tonų ir pustonių mirgèjime, leidžiančiame nusimesti nuo savęs aplinkos užneštą purvą, augti ir nuolat pildytis dvasiškai. Eilèraštyje tokiu pačiu pavadinimu „Šviesos spalvos" ir atspindima tokio dvasinio tapsmo metafizika:

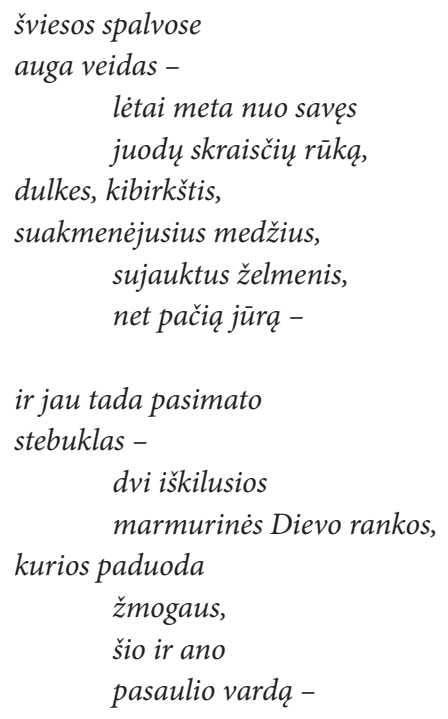

Minties ir vaizdo kryptis - labai vientisa: skleisti, teigti šviesaus Dievo pasaulio grožį. Sugestijos, asociacijos, vaizdų žaismo ir nuotaikos jungtys lemia ypatingą R. Mikutavičiaus eilèraščių skambesį. Reflektuojama beribė Dievo duota meilès galia, ir žmogui leidžianti keisti pasauli, akmenị paversti pavėsiu, o „tylejima prikelti iš mirusiu“ („myliu...., p. 85). Tačiau stipriai juntamas ir mirties, nykimo lauko poveikis žemèje: „Nyksta, išsisklaido, / kas turètų / ištisai žydèti - / negi / giliau už laiką, / erdvę, žmogu - / mirtis?“ („nyksta, išsisklaido...", p. 65). Vis dèlto pasaulị atperka Kristaus kančia, Jo kraujas, simboliškai pražydinantis žemę: "Liepsnoja / sunykęs Dievas. / Jo rankos ir kojos. / Liejasi Evangelijos / šviežias kraujas / i neatidrèkinama smèlyną. / O saule keroja. / Žydi žemé. / Kristaus veido spalva / tebespéliojama - / Golgotos paslaptis / amžina -“ („Golgota“, p. 93). Žemè nuolat gaubiama Kristaus didybės, todèl pagerbiama ir Jo Motina, pilna šviesos būties („Dievo Motinai“), pakiliai išgyvenamas kasmet žemėje pasikartojantis Kalèdų rojus („Kalèdos“). Dievoieškos temą pagilina iš kunigo minties perspektyvos atsiveriantis Dievo suvokimas - Jis atpažịstamas visur: gamtos pulsavime, jos grožyje, žmogaus atgailoje, mažose kaltèse, savyje. 
Gotikiniai bažnyčios bokštai iš tolo šaukia kaip nuolatinis šviesos ir tikejjimo priminimas, kad galima prikelti žemėn sutryptą būti, šlovinti saulę ir meilę. Skausmingai svarstoma ir pripažįstama tiesa, jog pargriuvimas leidžia išvysti ir pajusti tikrą̧ą šviesos erdvę: mirtis išlaisvina gyvybę, dangus praregimas, veidu kritus ị žemę, Dievas tiesą kalba, pargriautas ant medžio („Mirtis ir gyvybë“). Dvasinis žmogaus praregejjimas laukia tyloje: „Akmuo - / turbūt tik ribai, / vanduo - mirčiai / ir pažadinimui, // tikras stebuklas / vien Tyla, / kurioje auga / žmogaus žaizda“ („akmuo...", p. 113). Tyla reflektuojama kaip būtinybè žmogui pabūti su savimi, susitelkti ị savo dvasios erdvę, atrasti save. Kai kurie eilèraščiai, kuriami nuolankaus prašymo intonacija, virsta malda („Arkikatedroje“). Malda - svarbiausias kelias, žmogu priartinantis prie Dievo: „malda - / žydejjimas / giliame Dievo delne, / sočiai lyjant / tremties žaizdomis / ir pažadų ištarmèmis“ („Malda“, p. 119). Mediumu tampa ir Medis (Pasaulio medžio archetipas), kuriame apsireiškia Dievas, ịauginama ramybè, kuris spinduliuoja šviesą („Tikiu...“, p. 120), - taip poeto kūryboje susikerta krikščioniškosios ir archajinès lietuvių kultūros prasmès.

\section{RYŠIO PAIEŠKOS: KAD LIETUVA NEIŠSIVAIKŠČIOTŲ}

Religijos ir kultūros ryšys R. Mikutavičiaus poezijoje skleidžiasi įvairiomis linijomis. Vienas svarbiausių poeto kūrybos orientyrų - Lietuva, jos iškilūs žmonès su nepaprastais savo darbais. Tai kūrèjui tampa pagrindinėmis atramomis, nepakeičiamu vertybiniu pamatu. Bene ryškiausia figūra, kurioje poetas randa savo minčių ir išgyvenimų atgarsị, - Kristijonas Donelaitis, XVIII amžiaus Mažoji Lietuva, kurios likimas tampa savotišku XX a. antrosios pusès lietuvių visuomenès gyvenimo provaizdžiu. R. Mikutavičius tarsi eina savitos poetinės archeologijos keliu: giliai įsijausdamas eilèraščiuose atkuria senojo lietuviško būrų kaimo buitị, trobesių fasadus, duonos ir dūmo kvapą, šnekèseną, archajinius lietuviškus žodžius, - taip peržvelgiama matomiausia kasdienybės plokštuma, virtusi istorija ir užfiksuota Donelaičio Metuose. Reikšmingas yra visas realusis ir jau literatūriniu virtęs Mažosios Lietuvos pasaulèvaizdis: Lazdynèliai, Karaliaučius, Tilžè, Tolminkiemis, Gumbinès peizažas, būrų gyvenimo papročiai, etnografinès detalès, darbai, kančios, pats poetas K. Donelaitis - jo pasaulis tampa viena svarbiausių poetinio ciklo Kad Lietuva neišsivaikščiotų idejinių jungčių.

Istorinis laikas ir kontekstas poeto kūryboje tèra rèmai, išryškinantys egzistencinę patirtị. Pirmiausia tai - su Donelaičiu R. Mikutavičių artinanti žmogaus-kūrẻjo likimo trajektorija ir dvasininko, bažnyčios tarno, pozicija, iškeliant pasišventèlišką tarnystę kiekvienam mažajam, gebejjimas matyti kiekvieną nuskriaustą ir kenčiantį. „Vos tik nusisuku / nuo duondavio / atgiedoto psalmyno, / kiekvienas žvilgsnis / Būrą suranda - // rūsčia jo dalią, / kieta gyvenimo vyksma, / užslaptinta mąstyma, / žodžiu gražuma, / pakylantị virš pilkumu -“ („vos tik nusisuku“, p. 133). Centrine tampa „aš - mano būtis“ ašis: eilèraščiuose prabylama „aš“ vardu - tai Donelaitis, ieškantis nuskriausto, pažeminto Būro akių, kankinamas kalbos skriaudos, sunkios vargdienių dalios, atviras visai jų būčiai, giliai susisiejantis, susibendrinantis su jų likimais:

Ir kas aš be Būro?

pradetas nebaigtas,

gyvas negyvas,

einantis stovintis,

ką šaukti kaip savo galiu? 


\section{Ir kaip aš be Būro toliau? \\ tolstantis grižžtantis, \\ apšviestas blestantis, \\ skrendantis tupiantis \\ trečdalį amžiaus?}

(,ir kas aš be Būro?“, p. 136)

Lyrinis subjektas - kaukè - ypatinga lyrinio „aš“ raiškos forma, leidžianti kalbèti iš kito asmens pozicijų, prisiimti jo vaidmenị. Donelaitis R. Mikutavičiui artimas specifine savo kunigystès samprata, pagal kurią religija susiejama su tautiškumo aspiracijomis, prasmingu darbu kiekvieno tautiečio labui, neatmetant glaudesnio suartẻjimo su prigimtiniu jo pasauliu, šiuo atveju - žemdirbiškos kultūros pamatu. Lietuviškos bendruomenès vertybès iškeliamos kaip esminis egzistencinis poeto-dvasininko būties orientyras; taip klostosi vaizdus asmeninis iškiliojo lietuvių kūrèjo portretas - su visomis detalèmis, štrichais, atspindima jo pasaulëjauta, būties samprata. Iš praeities poetas tarsi perkelia ị mūsų dienas Donelaičio dvasinị taurumą, širdies gerumą, švelnumą, meilę savo tautos žmogui. Kaip ypatinga vertybė iškeliamas daugelio deklaruojamas, bet retai pasiekiamas, todẻl ir išskirtinis poeto gebejjimas suartèti su kitu, išgirsti kitq - kaip didžioji iškilaus žmogaus dvasios paslaptis, jo idealumo siekis ir egzistencijos šviesa:

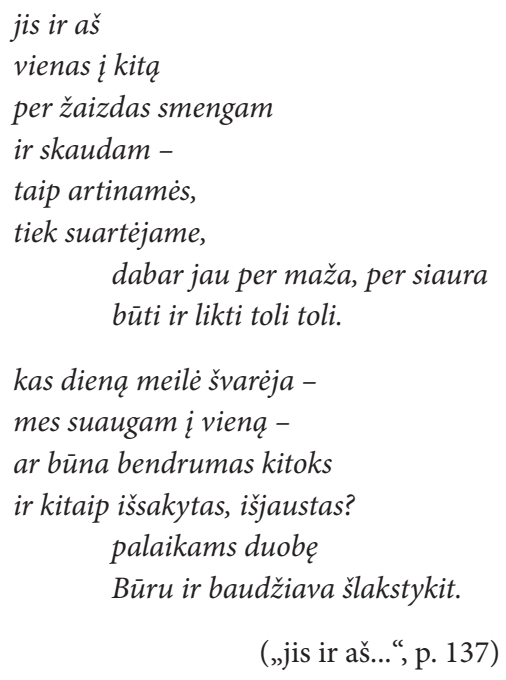

Poetas aktualizuoja Donelaičiui svarbias tautinès bendruomenès kūrimo, tiesioginio tautos narių artejjimo, visapusiško ryšio paieškas, jo pastangas suburti tautą, išsaugoti jos papročius, tradicijas, kalbą. Svarbiausią dramatinių išgyvenimų aši sudaro ịtampa tarp šiurkščios kasdienybės ir poeto siekiamo idealo polių: Donelaitis gyvena „viduryje apakusiu dienu“, kai itin svarbu „pakelti žodį / akims ir lüpoms, išvesti Kalba / tarp mirčiu, aprèpt bekraštę jos gyvybę“ („matyt...", p. 139). Iš skurdžios ir buitiškos aplinkos stebejjimo prabyla giluminis ir likiminis savos tiesos suvokimas, aktyviai išsakomas aukštų siekių ir vilčių sukurtas tikejjimas: „savos / šventos / Kalbos / išdaviku / nebūsiu!“ („,savos“, p. 142). Bažnyčia - vieta, kur susirinkusi atskirų individų, palinkusių mąstyti „ties altoriu paslaptimi“, gausybė turi virsti vieninga bendruomene, tauta, kur minia susispaudžia: „i tolima ryši auga / ir $i$ 
gilybę / ištiesia / visiems įrodyti / bendra gyvybę“ („offertorium“, p. 162). Poetinio subjekto figūra - be galo vientisa ir nesuskaldyta vidinių prieštarų, dar daugiau - akivaizdžiai siekianti jungti egzistuojančias priešybes ir ịkūnijanti pasiaukojančiojo lemtį: „Atidaviau save viena, / pasièmiau visus Bürus, / vienas įsispraudžiau ị Lietuva, / kad išžiūrèčiau / Visus amžius“ („atidaviau save vieną...; p. 140). Taip atsiliepiama ị evangelinę tiesą - būti pasauliui, kurti ji ir jam, ieškoti visokeriopų tarpusavio ryšių, atlikti savo dieviškąją misiją. Ši misija glaudžiai susijusi su atsakomybe gimtajai žemei, visam kraštui ir jo žmonėms. Eilèraščiuose Donelaičio pasaulèvaizdžio fone „irašoma“ ir paties poeto likimo trajektorija, jo sąmonès sklaida, atverianti vidinę iškilios individualybès dramą:

$$
\begin{aligned}
& \text { nebus gryno pelno sidabru- } \\
& \text { trisdešimt septynerius metus } \\
& \text { bažnytkaimyje } \\
& \text { vien su Būrais } \\
& \text { ir savimi, } \\
& \text { pačia sunkiausia viltimi } \\
& \text { ir neribotu laukimu } \\
& \text { nuo ankstyvo ryto kasdien } \\
& \text { iki lètai išsibaigiant } \\
& \text { per ilga nakti savaitemis, } \\
& \text { kapojamam vienodybiu, } \\
& \text { be mažiausio stabtelejimo } \\
& \text { prigludus prie stalo - } \\
& \text { ak, pats laimingiausias } \\
& \text { ir šviesiausias } \\
& \text { Žmogau! Kristijonai! } \\
& \text { Be gryno pelno sidabru! }
\end{aligned}
$$$$
\text { („nebus gryno pelno“, p. 141) }
$$

Kūrinyje tarsi persidengia kelios plokštumos - K. Donelaičio ir paties R. Mikutavičiaus gyvenimo tikrovè. Pasakojamoji stilistinė konstrukcija, lèta epiška kalbėsena tarsi „ižemina“ poetines gaidas, kuria paprasto, asketiško ir kartu nepaprasto savo didybe gyvenimo îspūdị. Tarsi prabylama „iš tylos“, iš nebūties, ir atveriamas skaudaus, slegiančio, bet neišvengiamo, būtino egzistencinio kelio liudijimas. İspūdinga poetinè saviprojekcija, alegoriškai išreikšta tarnystès tautai ir žmogui idejja metonimiškai atsiveria ir eilèraštyje „Savuoju grindiniu“:

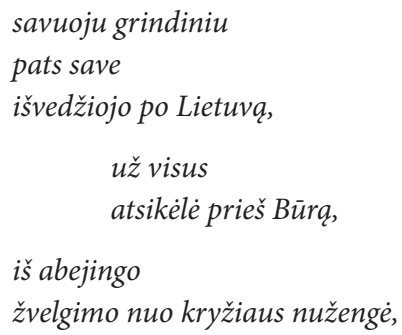




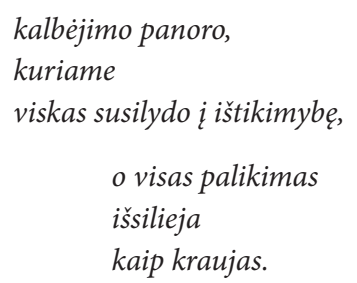

(p. 143).

R. Mikutavičius suranda tašką, kuris tarsi leidžia jam sulieti du laiko planus - donelaitiškąji ir savąjị, sutapatinti savo ir didžiojo lietuvių kūrèjo mąstymo klodus. Jis ịspūdingai peržvelgia praeitị ir dabartị, skirtingus ir panašius jų lygmenis, pabrěžia tai, kas yra universalu. Vaizduojamos situacijos atspindi abiem kūrèjams reikšmingus būties modelius ir tikslus: tam tikrą luomo ribų peržengimą, giliau einant ị žmogų, jo pažinimą ir dvasinị ugdymą, atveria jautrumą skriaudžiamiems ir niekinamiems bei siekị sukurti gerumo ir žmogiško atidumo atmosferą, išryškina ypatingą poetų pagarbą gyvenimui ir tẻvynei. Kartu R. Mikutavičiaus poezija manifestuoja poeto troškimą išsaugoti gyvą dabarties žmogaus ryši su praeities kultūra, praeitị, o aktualias dabarties laiko problemas paversti nūdienio žmogaus dvasinio gyvenimo savastimi. Donelaičio paveikslu jis ịprasmina tai, kas itin aktualu ne vien egzistencine, psichologine, bet socialine ir visuomenine prasme. Kalba - viena didžiausių vertybių Donelaičiui, todèl jo žodžiais išsakomas taurus noras rašyti, šviesti, nepasiduoti visuotiniam tautinès dvasios ir kalbos naikinimui:

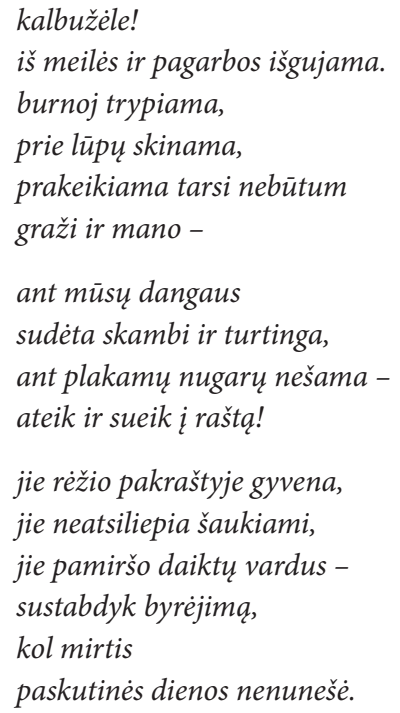

Poetas pabrèžia Donelaičio didybę, jo dvasios šviesą, bando apibrèžti jo vietą savos ir vèlesnių epochų horizonte („Pamokslas“). R. Mikutavičiui Donelaitis - pirmiausia drąsus žmogus, nepabijojęs parodyti žodžiui meilès, radęs žodžiui vietos savo darbuose, neuždusinęs kalbos liepsnos. Tai šimtmečio iššūkis, kuris veda ị tautos dvasinę laisvę. Donelaičio šviesą amžiams ịkūnija mažutè bažnytèlè („Šventovë“, „Žilvitis“), sauganti gyvastingus 
žodžius. Kviesdamas Donelaitị priartèti R. Mikutavičius tarsi subalansuoja visą XX a. antrosios pusès tautos dvasinių prarasčiu panoramą: „per pačiq suma neateik - / suraikèm siela dalimis, / išspjovem atminti, / kentèt mokẻjima palaidojom, / išrovèm mastymo šaknis $<\ldots>$ artèk artèk / per kita kertę / negu mūsų eita“ („Artèk“, p. 175-176). Tai priminimas tautai, kad eidama savo keliu ji dažnai neperima, neišmoksta to, ką jai perduoda ankstesnès kartos. Poetas nori priartinti amžiną išmintị, kurią ịprasmina Donelaitis, atverti tautai jos gyvenimui būtiną perspektyvą, atrasti ją iš naujo. Kad Lietuva neišsivaikščiotų.

\section{IŠVADOS}

Ričardas Mikutavičius - modernus kūrèjas, kurio religinès krypties poezijoje gyvai atgimsta giliai tikinčiojo žmogaus pasaulèvoka, ne prieštarų ir abejonių, egzistencinio dvilypumo kankinamo subjekto išgyvenimai, bet aiškiai savo kryptị žinančio žmogaus būties apmąstymai. Tikejjimas jo poezijoje suvokiamas kaip tiesa, egzistencinès šviesos šaltinis, atraminis taškas visai žmogaus būčiai, be kurio prasmingas buvimas neįmanomas. Medituoti dieviškąją tiesą ir paslaptị, religijos ir tikejimo inspiruotą dvasini ịkvėpimą - vienas svarbiausių R. Mikutavičiaus meninio pasaulio tikslų.

Šviesa - itin reikšmingas poeto kūrybos polius. Kūrèjo suvokimu, Dievas atnešęs pasauliui amžinybės erdvę, nuolatinę galimybę atsinaujinti ir kurti, alsuoti gèrio šviesa, nutolinančia nuo šiurkščios realybės. R. Mikutavičiaus poezijoje gyvenimas suvokiamas kaip buvimas Dievo dovanotose „šviesos spalvose“ - nesiliaujančiame šviesos tonų ir pustonių mirgejjime, leidžiančiame nusimesti nuo savęs aplinkos užneštą purvą, augti ir nuolat pildytis dvasiškai. Pagrindinę probleminę ašị poeto eilèraščiuose konstruoja žmogaus-kunigo, kuriam lemta išgyventi savą dramatišką žmogiškąji likimą, ir kunigo-žmogaus, privalančio nebijoti sudėtingos ir įvairialypės tikrovès, gebančio perprasti ir giliai svarstyti gyvenimo reiškinius, situacijos. Ir žmogaus, ir kunigo gyvenimas įprasminamas kaip amžina kelionè link tikrojo sielos apsivalymo, nuskaidrejjimo ir savęs atnašavimo pasauliui.

Svarbiausios strateginès linijos R. Mikutavičiaus poetinejje perspektyvoje - dvasininko, Kristaus tiesos ir meilès skleidejo, ir kultūrininko, pasišventusio tautai, jos dvasios gaivintojo, pozicijos. Iš čia kyla poeto kūryboje pagrindinẻ dvasinès tarnystės ir iš Evangelijų ateinanti meilès atnašavimo laikysena, tautos kultūrinių pagrindų ir dvasios namų ieškojimas. Reikšmingas jo kūrybos bruožas - pakilus eilèraščių tonas, religijos siejimas su kultūra, atsiveriantis ypatinga simbolika, kultūros kontekstais, kultūroje pabrèžiamais sacrum elementais.

Gauta 20111124

Priimta 20111227

\section{Literatūra}

[1] MIKUTAVIČIUS, Ričardas. Šviesos spalvos. Vilnius: Vaga. 1992.

[2] SKUNČIKAS, Romualdas. K. Trimako „Ieškančiojo pėdsakai“: poetinis Evangelijos apmąstymas. Iš: Vakarų Lietuvos katalikiškoji kultūra. II. Klaipėda: Lietuvių Katalikų Mokslo akademijos Klaipèdos židinys, 1992.

[3] NEMČINSKAS, Tautvydas. Architektūrinè poetika. Nemunas, 2010, liepos 22-rugsèjo 8 d., Nr. 27-28. P. 8.

[4] ŽUKAS, Vladas. Iš užrašų apie Ričardą Mikutavičių. Naujoji Romuva, 2008, Nr. 4(565). 
INGA STEPUKONIENĖ

\title{
Sparkle of the light of being in the lyrics by Ričardas Mikutavičius
}

\author{
Summary
}

Ričardas Mikutavičius is undoubtedly one of the most prominent and charismatic personalities in the second half of the 20th century in Lithuania: a priest, a genuine soul leader, an incredible preacher whose preaches were listened to by crowds of people, and a protector of cultural heritage: restorer of churches and collector of art works. He is the person who participated actively in social processes, influenced them, directed them towards a distinctive direction, and took care of the spiritual rebirth of the nation unconditionally. Mikutavičius is one of the most peculiar poets of the period, who continued and developed Christian topics and world-view in Lithuanian poetry. In this way he is related to other priests and creators: Maironis, Baranauskas, Vienažindys, Tumas-Vaižgantas. He is a modern creator whose poetry expresses the world-view of a deep believer; these are reflections of a person who clearly knows his / her direction rather than experiences, and suffers from existential duality. In his poetry, faith is understood as truth, the source of existential light and the base for all being of a person, without which a meaningful existence is impossible. This is the trend of religious Lithuanian poetry. Christian meditations are typical of his poetry; they express the divine mystery of the world, belief and obedience to God's will as well as search for the Truth and Meaning. One of the main aims of Mikutavičius's artistic world is to meditate the divine truth, mystery and spiritual inspiration caused by religion and faith. Mikutavičius's poetry is united to the spiritual base by philosophical being, feeling the existential mystery, striving for the revelation of spiritual truths and experience of life and being miracle. Light is one of the most important poles in his poetry. God brought to the world eternity, the permanent possibility to renew and create, and to breath the light of goodness, which dissociates from the rudeness of reality. Life in Mikutavičius's poetry is conceptualized as being in the 'colours of light' presented by God, in the continuant sparkling of light tones and undertones, which allows to reject the dirt imposed by the environment, to grow up and develop spiritually. Two strategic perspectives intersect in his poetic perspective: a priest who disseminates Christ's truth and love, and a person of culture devoted to his nation and reviving its spirit. This is the central position of his poetry: spiritual ministry and love inspired by the Gospels and the search of the cultural base and spiritual home of the nation. A significant feature of his poetry is the high tune of the poems, the relation between religion and culture, which is expressed by special symbols, cultural context and an emphasis on sacrum elements in culture.

Key words: poetry by R. Mikutavičius, religious poetry, Christian meditation 